\section{Rachel Carson, Silent Spring, and the Environmental Movement}

\author{
Caula A. Beyl
}

Additional index words. pesticide, DDT, organic movement, organophosphates

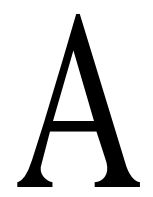
lmost 30 years after its publication, the book Silent Spring (Carson, $1962 b$ ) is instantly recognized, evoking ominous images of DDT, bird and fish kills, and pesticide danger. The book can still galvanize reaction in readers and engender controversy.

Carson's message was delivered in a vivid, beautiful, and effective style, and the book's credence was enhanced by Carson's substantial reputation as a scientist and a writer. Also, the book arrived soon after the tranquilizer thalidomide was revealed to cause birth defects, adding to Silent Spring's impact (Brooks, 1970; Eiseley, 1962). Carson did what few authors have been able to-she tied the diverse facets of information about pesticide abuse and ubiquitous exposure, biological magnification, and environmental impact into one story that was eminently readable and understandable by a general public not steeped in science. The first chapter, "A Fable for Tomorrow," much-criticized because it was a fictional account resembling a Gothic tale, tells of a town where "all life seemed to live in harmony with its surroundings" (Carson, 1962b). Then a "strange blight falls upon that town and the countryside "famous for its abundance and variety of its bird life." The description of the blight and its effects gripped the reader in a way that no cold, calculated recitation of fact could. The unfolding of omnipresent danger compels attention to the message. When she wrote Silent Spring, Carson had no illusions about what the book could accomplish. When the manuscript was almost finished, she wrote to a close friend, "It would be unrealistic to believe that one book could bring a complete change" (Brooks, 1972). She herself failed to anticipate the enormous and enduring impact of Silent Spring.

\section{Rachel Carson, the woman}

Examination of Carson's early life does not indicate she was the type of person to take on the

Department of Plant and Soil Science, Alabama A\&M University, Normal, AL 35762. mantle of crusader. Born in Springdale, Pa., in 1907, she was a quiet child, describing herself as somewhat solitary and having spent a great deal of time in woods and beside streams, learning the birds and the insects and flowers (Brooks, 1972). She had always intended to be a writer and published her first story at age 11 . While preparing in college for a writing career, Carson changed majors from English to biology after taking a required biology course, even though she was warned that "there was no future for women in science apart from teaching in high schools or obscure colleges" (Gartner, 1983) and that "science was too rigorous a field for women" (Hynes, 1989). While she was pursuing undergraduate and graduate degrees, it never occurred to her that it would be possible to combine the two areas that interested her so much-writing and biology. A fellowship for summer study at Woods Hole Marine Biological Laboratory after her undergraduate degree gave her the first chance to see the ocean (Fig. 1). She completed her master's degree from Johns Hopkins Univ. in 1932. No one reading the title of her master's thesis, "The Development of the Pronephros During the Embryonic and Early Larval Life of the Catfish (Inctalurus puncfatus)," would guess that this is the same author who later wrote captivating best-sellers about the sea.

Her first professional position after graduation, as a part-time script writer for the then Bureau of Fisheries, led to 17 years with the Fish and Wildlife Service, culminating in the position of editor-in-chief (Gartner, 1983). It was during this time that she began writing about the sea; her first book, Under the Sea Wind, appeared in 1941. Although the book was reviewed favorably by the scientific community, the public was preoccupied with the aftermath of Pearl Harbor and sales were low. Carson's royalties were less than $\$ 1000$, which almost convinced her that book writing was a poor-financial gamble (Brooks, 1972). But her second book, The Sea Around Us, which appeared in July 1951, reached the best-seller list in September and was selling more than 4000 copies a day by December. Carson established a pattern, for this and future books, of releasing chapters for magazine publication before the book was published. Her third book, The Edge of the Sea, was released in 1955 after serialization in the New Yorker magazine (Brooks, 1972). The phenomenal success of her books enabled Carson to resign from her position with the U.S. Bureau of Fish and Wildlife Service in 1952 (Gartner, 1983). She received many awards, recognition, and even honorary doctorate degrees for her books. Thus, when Silent Spring appeared, she was not only a well-known "scientist cum author," but she had the necessary financial foundation and lack of constraints imposed by government or university ties to write with an extraordinary sense of freedom.

In the 3 years after publication of The Edge of the Sea and beforeshe began work on Silent Spring, Carson continued to write. She produced a script about clouds for the television program "Omnibus" and an article for Woman's Home Companion, "Help Your Child to Wonder" (Brooks, 1972).

Silent Spring was a radical departure from her previous writings on the wonders inherent in the sea. She did not decide casually to take up the cause of pesticides and their impact on the environment, butassumed the burden rather reluctantly. In 1958 she received a letter from Olga Huckins, a former writer for the Boston Post, describing the devastation wrought upon insectsand particularly bird life in her private bird sanctuary north of Cape Cod by an aerial spray of DOT and fuel oil for mosquito control. Huckins had hoped that Carson would be able to find someone in Washington who could help stop further mass spraying. When she was unable to get action, Carson realized that she

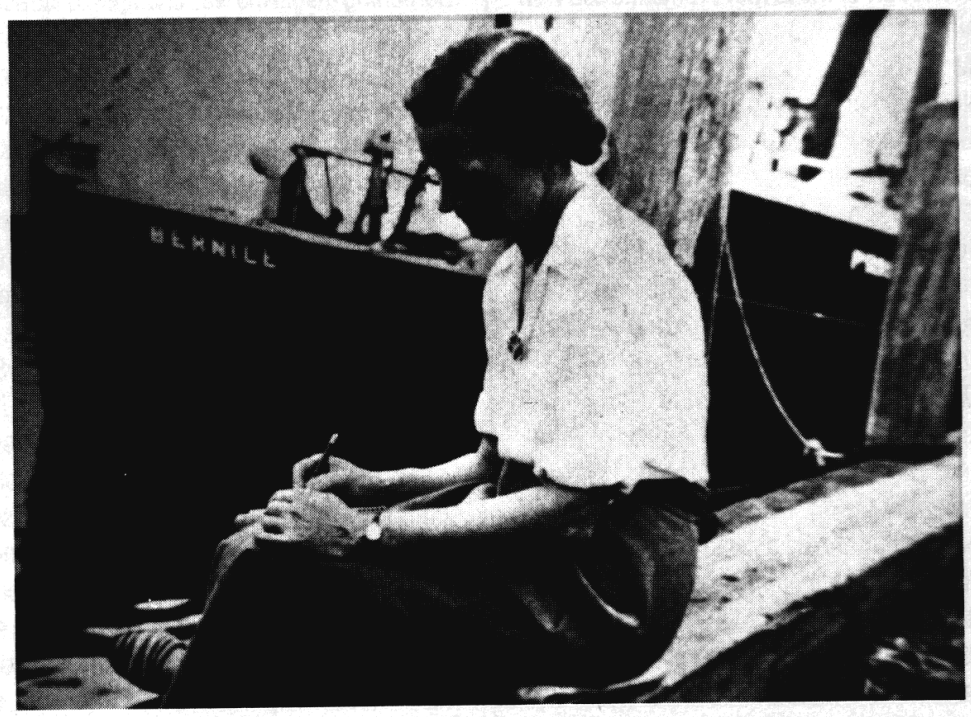

Fig. 1. Carson in 1929 when she was awarded a fellowship for summer study at Woods Hole Marine Biological Laboratory. This was the year that she first viewed the ocean. 


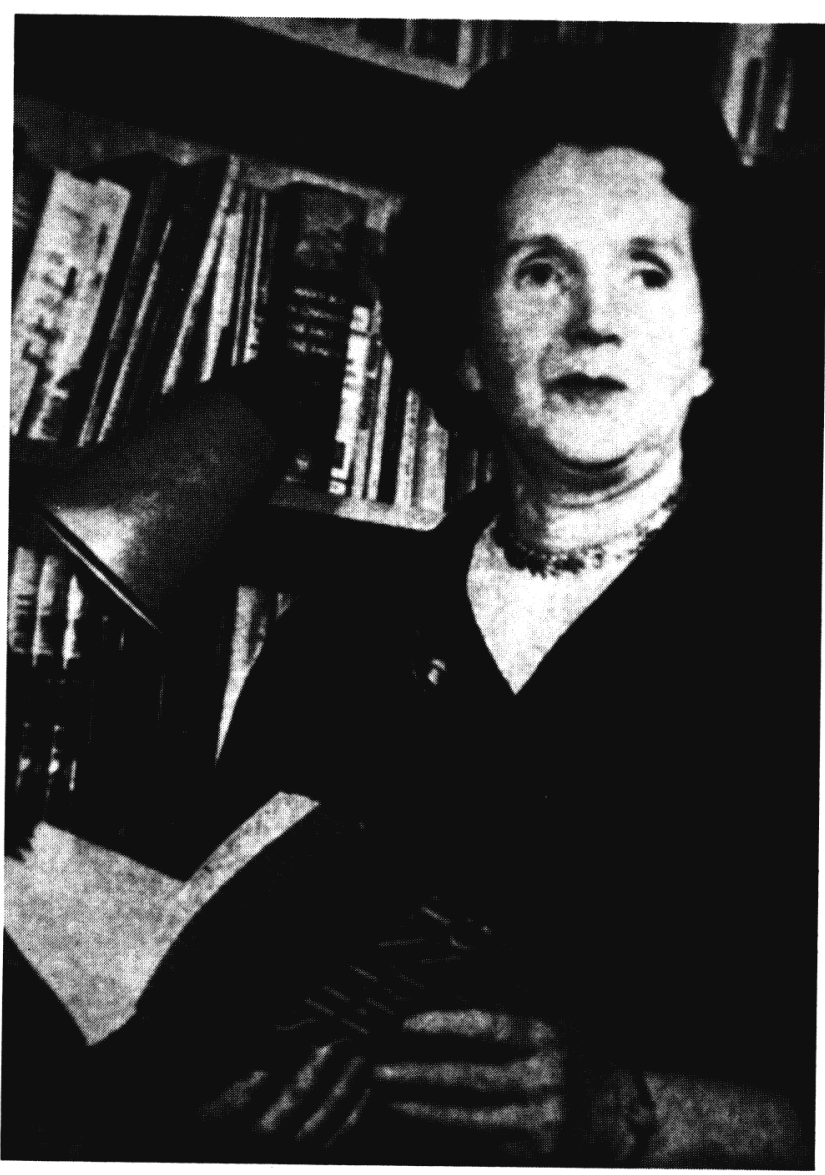

Fig. 2. Carson in 1962, holding Silent Spring. The book dramatically changed public perceptions about the use of pesticides.

would have to do it herself (Graham, 1970). Silent Spring grew from a magazine article into a fullblown book that took $41 / 2$ years to write.

Undertaking a book on the topic of pesticides and the environment with particular attention to the persistent chlorinated hydrocarbons required a tremendous amount of personal courage. At that time, publicity about DDT was voluminous and overwhelmingly positive. It had the advantages of being inexpensive and easy to make (Brooks, 1970). It was not considered a hazard to human health if used with discretion (Whorton, 1974). One clipping service of an American newspaper accumulated almost 21,000 items about DDT in 18 months between 1944 and 1945 (Davis, 1971). Even though there was early recognition of the problem with DDT's persistence, accumulation in animal fatty tissues, biological magnification through the food chain, and reports of immunity developed by the common housefly (Brooks, 1970) Carson knew "that by taking up her pen to write honestly about this problem, she had plunged into a sort of war" (Graham, 1970).

She finished Silent Spring in spite of personal and family pressures-the adoption of her 5-year-old, grandnephew Roger Christie, the loss of her mother after a long illness, and recurring personal illnesses, including arthritis, an ulcer, staphylococcus infections, and ultimately cancer
(Gartner, 1983). Silent Spring first appeared as an extended three-part article in the New Yorker (Carson, 1962a). The responses, both pro and con, were immediate and overwhelming. Even before release, Houghton Mifflin was threatened with a lawsuit because of putative inaccuracies in the representation of chlordane and heptachlor (Brooks, 1972).

\section{Silent Spring- Action and reaction}

Silent Spring became an instant best-seller (Fig. 2)) remaining on the New York Times' list for 31 weeks (Newsweek, 1964). The advanced release in the New Yorker resulted in more than 50 newspaper editorials and roughly 20 columns (Hynes, 1989). By the time the book was published in Sept. 1962, advanced salesalready had reached 40,000 copies, and by December 100,000 copies had been sold (Brooks, 1970). By the end of the year, more than 40 bills in different state legislatures had been introduced governing the regulation of pesticides use (Hynes, 1989). The book is still in print.

There were serious attacks. In the Saturday Evening Post, Edwin Diamond stated, "Thanks to a emotional, alarmist book called 'Silent Spring,' Americans mistakenly believe their world is being poisoned" (1963). The New York Times printed
"She tries to scare the living daylights out of us and, in large measure, succeeds" (1962). This contrasts with what LaMont Cole, professor of ecology at Cornell, wrote in the Scientific American: "Errors of fact are so infrequent, trivial, and irrelevant to the main theme that it would be ungallant to dwell on them" (Cole, 1962).

Personal attacks were made on the author in an attempt to counter and diffuse the enormously persuasive case that she had built. She was labeled a "bird lover," "cat lover," "fish lover," "nun of nature," and "priestess of nature" (Graham, 1970). She was accused of "worrying about the death of cats but not caring about the 10,000 people who die daily from malnutrition and starvation in the world" (Diamond, 1963). It is true that she liked cats-her favorite often kept her company when she wrote. [Her love of cats seems hard to reconcile with her love of birds, but cats, she said, were only being "true to their own nature" (Life, 1962)]. Much of the personal attention focused on her being an hysterical, unmarried woman-a spinster. Life magazine stated that she was "unmarried but not a feminist" and quoted her as saying, "I'm not interested in things done by women or by men but in things done by people" (Life, 1962).

She may not have been a feminist in the classical sense of the label, but she was proud of her achievements as a woman. She was one of the first few women other than secretarial staff in the Fish and Wildlife Service (Hynes, 1989) and in 1963 she was the first woman to receive the Audubon medal for conservation achievement (Vosburgh, 1964). Many of her detractors would have liked to forget that she was truly a scientist and had received excellent training. She thoroughly researched the information used in Silent Spring because she wanted it to be "built on an unshakable foundation" (Brooks, 1970); it included 54 pages of references. That she was a scientist as well as an author was acknowledged in the citation on the Audubon medal (Vosburgh, 1964):

Distinguished scientist, gifted writer,

Sensitive and perceptive interpreter of the ways of nature,

Who authored a book called SILENT SPRING;

Through it she alerted and aroused the public about needless and dangerous chemical pollution of our environment And sounded a timely warning that technology, run away from science, can be a threat to man.

She also was accused of being biased and hysterically overemphatic (Brooks, 1972; Udall, 1964). The New York Times book review stated, "Silent Spring is so one-sided that it encourages argument, although little can be done to refute Miss Carson's carefully documented statements" (Milne and Milne, 1962). Life magazine said, "there is no doubt that she has overstated her case" (Life, 1962) but also pointed out that the 
case for chemical pesticides that was being aired by chemical manufacturers was just as one-sided, but in the other direction. Parodies of Silent Spring were written and released in an effect to counter or soften the message. One such parody was entitled "The Desolate Year" and described a bleak future without pesticides. Another called "Quiet Summer" depicted a boy and his grandfather eating acorns-as a result of lack of pesticides they had been forced to "live naturally" (Brooks, 1972). Fact kits were distributed to members of the medical profession (Brooks, 1970; Graham, 1970); one developed by the Nutrition Foundation contained copies of critical book reviews, a defense of chemical pesticides, and a letter from the president of the foundation indicating that the "book was distorted" (Brooks, 1972; Graham 1970). Their defense of chemical pesticides as they were used centered around four main points. First, that chemical sprays and other advanced technology had made possible huge surpluses of agricultural commodities. Second, that chemical pesticides had been instrumental in eliminating many diseases whose vectors were insects. Third, that while chemical pesticides did disrupt the "balance of nature," it was in favor of man. And fourth, that pesticides were safe when used properly (Senior Scholastic, 1962). Carson also was accused of exaggeration and sensationalism: “...what I interpret as bias and oversimplification may be just what it takes to write a best seller" (Diamond, 1963).

Was there bias? Was the implied link to cancer an oversimplification? The Economist accused her of making a "propaganda play" with the cancer statistics implying an "alarming" increase in cancer (1962). The implication that chemicals in the environment were the cause of cancer was implicit in Silent Spring without provision of a specific cause-and-effect relationship. We are now much more cognizant about the wide range of carcinogens in our environment, and many pesticides are now known to be carcinogens. It is still unclear whether Carson exaggerated the cancer threat and its link with pesticides by interpreting cancer statistics in a manner that supported her assertions, or whether she was correctly intuiting thethreat. Cancer statistics are not easy to interpret if cancer death is considered apart from incidence, and the data can be obfuscated even further by making a critical examination of the statistical base used (Gartner, 1983).

Public attitudes and perceptions at that time are reflected in political cartoons that appeared in various newspapers and magazines, and Brooks' biography of Carson (1972) has an excellent collection. One that appeared in the New Yorker in 1963 depicts a woman standing in front of a display of pesticides in a garden store saying to the salesperson, "Now, don't sell me anything Rachel Carson wouldn't buy" (Newsweek, 1963).

Why did Silent Spring so arouse the pesticide industry and agricultural community7 Many of those who attacked the work apparently did not read it carefully or did not care to report it accurately (Brooks, 1970). Diamond stated, "Nor has anyone, with the possible exception of Miss Carson, proposed to abolish pesticides" (1963). Did she advocate banning pesticides, as was stated and implied many times by those trying to minimize the book? Her feelings concerning pesticide use are best summarized on page 12 of Silent Spring. "It is not my contention that chemical insecticides must never be used. I do contend that we have put poisonous and biologically potent chemicals indiscriminately into the hands of persons largely or wholly ignorant of their potential for harm..". In Audubon magazine she wrote, "We do not ask that all chemicals be abandoned. We ask moderation. We ask the use of other methods less harmful to our environment" (Carson, 1963). Countering claims that she was advocating a back-to-nature philosophy, she said, "We must have insect control. I do not favor turning nature over to insects. I favor the sparing, selective and intelligent use of chemicals. It is the indiscriminate, blanket spraying that I oppose" (Frisch, 1964). Two weeks after her death this was reemphasized in the New Yorker "She was not a fanatic or a cultist. She was not against chemicals, per se. She was against the indiscriminate use of strong, enduring poisons capable of subtle, long-term damage to plants, animals, and man" (1964).

The evolution of the books title in a sense reflects the evolution of its message, which is as much about human arrogance as it is about specifics. The tentative first title, The Control of $\mathrm{Na}$ ture, became Man Against the Earth and ultimately Silent Spring (Brooks, 1970). The theme of a spring without the songs of birds was reinforced by two lines from Keats on the motto page, "The sedge is wither'd from the lake, And no birds sing." Carson believed that humanity does not stand alone and that, like all other living things, we are a part of our environment. Anything that threatens our environment ultimately threatens us. She also challenged the concept of safe tolerances, citing examples of synergism and chronic effects. She maintained that people have a right to live without being endangered by wide-scale pesticide application about which they have no choice and from which no recourse. Considering the ability of insects to develop resistance to chemical pesticides, she suggested that there are ecologically safe alternatives (many of which are commonly used today). She gave us a different view of pesticide persistence, not as an asset but as a danger. In the case of the chlorinated hydrocarbons, she pointed out that they were subject to biological magnification through the food chain. She felt that the maximum permissible tolerances established by the government gave a false sense of security and did not reflect cumulative or interactive effects. She maintained that chemical pesticides in use at that time were not selective and did not distinguish pest from beneficial. It was far better to control insects that caused diseases or destroyed crops

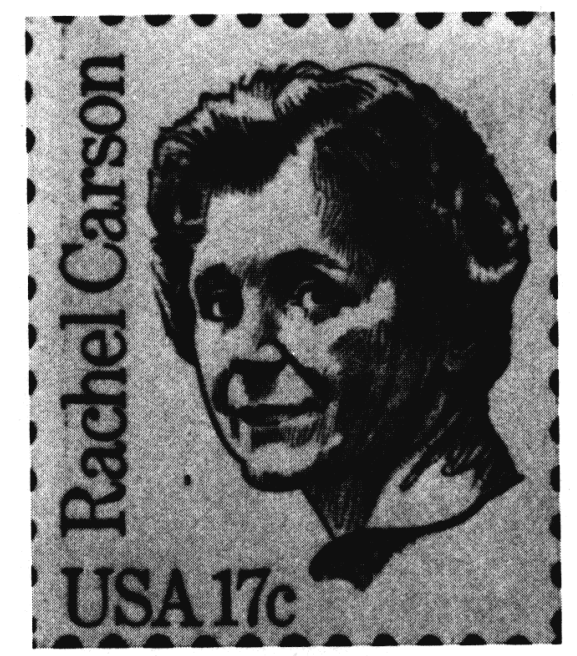

Fig. 3. The Rachel Carson stamp issued in 1981.

with methods that did not wreak havoc with the entire natural world (Carson, 1962b). It is hard to believe, looking at this from a 1991 perspective, that this message could have generated such angry rebuttal and response.

Some of the subtleties conveyed in Silent Spring were missed even by those who later wrote about the crucial role that Carson played in helping alert the public to the need for an environmental movement. In a footnote to the introduction to Hynes (1989) there is a description of a classic cartoon that had come out concerning Carson. The footnote states, "A grasshopper prays, 'God bless Momma and Poppa...and Carson." In fact, the "grasshopper" was a praying mantis, and the author missed the whole concept of protecting beneficials that was exploited by the cartoon.

The day after Carson's appearance on CBS Reports on 3 Apr. 1963 to defend Silent Spring against a panel of agricultural, government, and chemical representatives, Senator A. Ribicoff said before the Senate, "there is an appalling lack of information on the entire field of environmental hazards. We face serious questions, but we are woefully short of answers" (Brooks, 1972). His statement repeated the assertion on page 13 of Silent Spring, that "we have allowed these chemicals to be used with little or no advance investigation of their effects on soil, water, wildlife, and man himself." In her testimony before the senatorial subcommittee that stemmed from Silent Spring, Carson reiterated that she did not advocate abandoning pesticides but called for tighter supervision (Newsweek, 1963). She also called for the right of individuals to protection against pesticides applied by others, legal redress for those harmed by them, restrictions in sale and use to those capable of understanding the hazards, approval of new pesticides only if no existing methods were available, and full support to research new methods of pest control minimizing chemical pesticides. 


\section{Impact}

Publication of Silent Spring resulted in a request to President J.F. Kennedy's Science Advisory Committee to study the problem. Their report, according to a statement published in Science, was a "thorough-going vindication of Carson's Silent Spring thesis" (Graham, 1970). The committee report criticized the federal government's eradication programs, such as those directed against the gypsy moth, fire ant, Japanese beetle, and whitefringed beetle (Greenberg, 1963). It called for improved coordination between federal agencies, immediate reduction of the use of DDT with eventual elimination as a long-term goal, echoed concerns about persistent pesticides, and raised alarm about a general nonchalance for human safety. The report exposed the loophole through which pesticides denied approval by the U.S. Dept. of Agriculture (USDA) could reach the public. If the manufacturer protested the USDA decision, the USDA was forced to grant certification, which was good for 5 years, unless the agency was able to prove the pesticide dangerous (Greenberg, 1963). This "protest registration" loophole was closed in 1964 (Brooks, 1970). The committee also called for expansion of research into specific controls, chronic effects, and synergism or potentiation of pesticide toxicity by commonly used drugs.

It is difficult to determine definitively what events directly resulted from the publication of Silent Spring, because by 1962 there was an awareness of the negative aspects of DDT and many of the "hard" pesticides by part of the scientific community (Hynes, 1987). DDT, which played a lead role in the book, was already under scrutiny for its ability to accumulate in fatty tissues of animals and, presumably, humans. Perhaps the most enduring effect of the book was to change public perception (Shea, 1973) of the role of pesticides from that of innocuous beneficial tools of man, having negligible costs, to a tool whose benefits may be offset by yet unknown costs. This changed perception was not confined to the United States. Carson's name and book were invoked many times before the House of Lords in England in 1963, resulting in controls on the use of aldrin, dieldrin, and heptachlor (Newsweek, 1964a). The book was published in France, Germany, Italy, Denmark, Sweden, Norway, Finland, Holland, Spain, Brazil, Japan, Iceland, Portugal, and Israel and stimulated environmental legislation in all of them (Brooks, 1972; Hynes, 1987).

Silent Spring was the impetus for the founding in 1967 of the Environmental Defense Fund, which later led the battle to ban DDT. The arguments used in the court hearings reflected the majorpoints made in Silent Spring (Hynes, 1989). After 1962, multiple federal laws and hundreds of state laws were enacted governing protection of air and water, wildlife, and humans from the effects of pesticides, their manufacture, and disposal. The growth in federal environmental legislation was exponential (Hynes, 1989). In 1970 the Environmental Protection Agency was created with a mission to protect the total environment.

Silent Spring has been called one of the most influential books of the 20th century (Shea, 1973), and Carson was selected by Life magazine as one of the 100 most important Americans of the 20th century (Life, 1990). Unfortunately, she did not live to see anything but the immediate outcome of her work. Although she was dying of cancer, Carson did not lack a sense of humor. When queried about what she ate, she answered, "chlorinated hydrocarbons, just as everybody else does" (Graham, 1970). Even after her death in 1964 from heart disease and complications of cancer, awardsand honors continued. The Rachel Carson National Wildlife Refuge in Maine containing $96 \%$ coastal salt marsh was dedicated in 1970 (Briggs, 1970). In 1980 President J. Carter awarded her the Presidential Award of Freedom accepted on her behalf by her adopted son, Roger Christie. The medal was inscribed in part, "...she created a tide of environmental consciousness that has not ebbed" (Gartner, 1983). In 1981 the Carson stamp (Fig. 3) was issued by the U.S. Post Office in Springdale, Pa., her birthplace (Gartner, 1983).

When she was asked why she did not defend her book more vigorously, she answered, "Let the course of events provide the answers" (Graham, 1970). Time has proven that she was as much prophet as writer and scientist. Silent Springwas a landmark event stimulating the growth of the environmental movement. How different this is from the prediction made by White-Stevens at the Synthetic Organic Chemical Manufacturer's Assn. in 1962: "On the whole, her book will come to be regarded in time as a gross distortion of the actual facts, essentially unsupported by either scientific experimental evidence or practical experience in the field" (Van Fleet, 1963). In 1972 a newspaper editor wrote of Carson, "A few thousand words from her and the whole world took on a different direction" (Murphy, 1991). There is hardly a newspaper or magazine now that does not reflect this increased environmental awareness in some form on its pages.

One wonders what Carson would choose to write about now.

\section{Literature Cited}

Briggs, S.A. 1970. Remembering Rachel Carson. Amer. Forests 76:8-11.

Brooks, P. 1970. Silent Spring. The genesis and the storm. Audubon 72:70-72.

Brooks, P. 1972. The house of life. Houghton Mifflin, Boston.

Carson, R. 1962a. Silent spring. New Yorker 16 June, 38:35-40; 23 June, 31-36; 30 June, 35-42.

Carson, R. 1962b. Silent spring. Houghton Mifflin, Boston.
Carson, R. 1963. Rachel Carson answers. Audubon Sept., 65:262-265.

Cole, L.C. 1962. Book review of Silent Spring. Sci. Amer. Dec., p. 173-180.

Davis, K.S. 1971. The deadly dust: The unhappy history of DDT. Amer. Heritage Feb., 22:44-47.

Diamond, E. 1963. The myth of the "pesticide menace." Saturday Evening Post 28 Sept., 236:16,18.

Economist. 1962. Review of Silent Spring. Economist (London) 20 Oct., p. 248-251.

Eiseley, L. 1962. Using a plague to fight a plague. Saturday Rev. 29 Sept., 45:18-19,24.

Frisch, B.H. 1964. Was Rachel Carson right? Sci. Dig. Aug., 56:39-45.

Gartner, C.B. 1983, Rachel Carson. Frederick Ungar, New York.

Graham, Jr., F. 1970. Since Silent Spring. Houghton Mifflin, Boston.

Greenberg, D.S. 1963. News and comment. Pesticides: White House Advisory Body issues report recommending steps to reduce hazard to public. Science 140:878879.

Hynes, H.P. 1987. The recurring silent spring. Pergamon, New York.

Life. 1962. Gentle storm center. Calm appraisal of silent spring. Life 12 Oct., 53:105-106.

Life, 1990. Rachel Carson: A prophet's early warning of a planet in trouble. The 100 most important Americans of the 20th century. Life, Fall ' 90 .

Milne, L. and M. Milne. 1962. There's poison all around us now; the dangers in the use of pesticides are vividly pictured by Rachel Carson. New York Times Book Rev. 23 Sept., p. 26.

Murphy, R.J. 1991. Friend of the earth. House Beautiful Apr., p. 146.

New York Times. 1962. Silent spring is now noisy summer. New York Times, 22 July.

New Yorker. 1964. Notes and comments. New Yorker 2 May, 40:35.

Newsweek. 1963. Pests and poisons. R. Carson before Senate Investigative Subcommittee. Newsweek 17 June, 61:86.

Newsweek. 1964. A life in nature. Newsweek 27 Apr., 63:95.

Senior Scholastic. 1962. The furor over pesticides. Senior Scholastic 12 Dec., p. 10-12.

Shea, K.P. 1973. A celebration of Silent Spring. Environment 15:4-5.

Udall, S.L.. 1964. The legacy of Rachel Carson. Saturday Rev. 16 May, 47:23,59.

Van Fleet, C.C. 1963. Silent Spring on the Pacific Slope. A postscript to Rachel Carson. Atlantic Monthly 212:8184.

Vosburgh, J. 1964. Carson receives Audubon medal; with acceptance address. Audubon Mag. 66:98-99. 